\title{
Zum 70. Geburtstag des Herrn S. Karger
}

Herr S. Karger konnte am 21. Mai in bewundernswerter Frische seinen 70. Geburtstag begehen. Zu diesem seinem Ehrentage überreichten ihm die Herausgeber seiner Zeitschriften und Autoren seines Verlages unter Führung von Herrn Geh. Rat. Prof. Dr. Martin eine Sammlung von Adressen, in denen sein Lebenswerk auf den verschiedensten Gebieten der Heilkunde gebührend gewürdigt wird. Aus kleinen Anfängen heraus hat Herr Karger seinen Verlag mit nie erlahmender Tatkraft und unerschütterlichem Unternehmungsgeist bald zu einer im In- und Ausland hochgeachteten Stellung emporgehoben. Auch unserer Zeitschrift, die er 1893 mit O. Lassar begründete und zum Publikations-organ der Berliner Dermatologischen Gesellschaft machte, widmete er allezeit sein besonderes Interesse und hielt sie trotz der Fährnisse ungewöhnlicher Zeiten auf der Höhe. Noch vor kurzem gab er ihr durch Einführung von Sammelreferaten einen neuen Antrieb. So ist es mir eine große Freude, ihm im Namen aller Mitherausgeber und Mitarbeiter auch an dieser Stelle die herz-lichsten Glückwünsche aussprechen zu können; möge ihm seine bewunderns-werte Arbeitskraft und Schaffeñslust noch viele Jahre erhalten bleiben.

Erich Hoffmann. 